\title{
Study of Factors Causing Cost Overrun in Construction Industry Using AHP Technique: A Review
}

\author{
Shah Mohd Shahbaz ${ }^{1}$, Sohit Agrawal ${ }^{2}$, Dr. Mukesh Pandey ${ }^{3}$ \\ ${ }^{1}$ B.Tech+M.Tech(INT) P.G student, Construction technology and Management, I.T.M University Gwalior, \\ Madhya Pradesh,India \\ ${ }^{2}$ Asst. Professor Dept. of Civil Engineering, I.T.M University Gwalior, Madhya Pradesh, India \\ ${ }^{3}$ Head of Civil Engineering, I.T.M University Gwalior, Madhya Pradesh, India
}

\begin{abstract}
Cost overrun has become a serious problem in construction sector. When the project could not be completed in estimated time at given budget then cost overrun occurs which is excess of actual cost over budget. These overruns have harmful impact on the financial system of country. Cost overrun have several factors that don't seem tobe taken into consideration at the time of planning resulting into delays and cost will increase. Within the study, we've got studied literature and known those factors influencing cost overruns. The primary findings emanating from the study disclosed that empirical studies have known variety of necessary factors that cause project cost overruns. These factors are categorized into several group depending on their category. It is found that understanding the cause of such factor by construction manager should help to avoid or minimize the cost overruns and gives better cost performance over the life of
\end{abstract} the project.

Keywords: Cost Overrun, Construction Project, Construction Cost, National Economy, construction industry

\section{INTRODUCTION}

Construction industry is a vital industry that plays a significant role within the socio-economic growth of the country, particularly developed countries. This industry contributes to the GDP and employment rate of the many nations and for this reason it's considered important for the economic development of nation. The increasing complexness of infrastructure projects and the atmosphere within which they are constructed place greater demand on construction managers to deliver projects on time, within the planned budget and at given time. Cost overruns in construction projects result in a rise within the capital- output-ratio for the whole economy. The cost overruns have became hallmark of infrastructure projects in India. Despite of the project management there has been a need arisen to research out the various factors/causes of cost overruns because it hinders the progress of the construction project. It is necessary to determine the reasons of various causes of cost overruns in construction industry by knowing the opinions from the member which are concerned in construction industry. This study is carried out to understand and dig out the major factors resulting in cost overruns in construction industry which helps in improving the performance of the construction industry.

\section{OBJECTIVE}

The problem of cost overrun, particularly within the construction industry, is a worldwide phenomenon. A project in the construction is considered successful if it is completed on time, within budget and to specification or quality standard. However, in the recent past it is seen that most projects get delayed due to certain factors leading to cost overrun. Thus, this study is carried out to find the major factors that are leading to cost overrun or overrun of estimated budget by using AHP(Analytical Hierarchy Process) technique. AHP is multiple criteria decision making (MCDM) Method in which questionnaire has been made for different factors and distributed to construction parties for survey and are calculated through analysis by AHP method.

\section{LITERATURE REVIEW}

Various literatures were studied to get an overview of construction cost overruns factors and minimizing their effects on the construction project in the most economical way and to understand various research studies associated with efficient and economic ways of construction.

\section{S. Shanmugapriya, Dr. K. Subramanian(October} 2013) carried out research work on vital factors inflicting Time and Cost overruns in Indian construction projects. A questionnaire form was created for survey based on factors for time and cost overrun determined from previous literature review. Factors were sorted and grouped into twelve categories for time and cost overruns there is eight 
categories and distributed to Contractors, Consultants, and Owners of Indian construction Industry. The information or data from the questionnaire was analyzed. RII method was used to find the most critical factors which effects the time and cost overrun in construction projects. Results shows that the cause for time overrun are material market rate, contract modification and high level of quality requirement the cause for cost overrun are high transportation cost, change in material specification and material price escalation. The study helps to reduce the cost overrun and delays in construction sectors.

A. M. El-Kholy(2015), used and represented two models for predicting cost overrun percentage in construction projects. The primary model is predicted on regression analysis. Fourtyfour factors collected from literature that impact cost performance in construction. Eleven important factors that's leads to overrun are found to be independent variables of the projected model. information was collected for incidence of the previous factors on yes or no basis and additionally the corresponding overrun percentage for thirty construction projects and were divided into two sets. The results shows that there is a powerful linear relationship between cost overrun percentage and also the previous eleven causes that considerably have an affect cost overrun of projects. The second model is a case based reasoning (CBR) model. CBR method can be used to find percentage cost overrun by utilizing knowledge gained from past experience. Study shows that regression model has a prediction capabilities high than CBR model.

D $\mathbf{S}$ Tejale in paper "Analysis of Construction Project Cost Overrun by Statistical Method"(may 2015) carried out a work on studying significant factors inflicting cost overruns in construction projects. A questionnaire form for survey was prepared by Authors based on fourty five common factors for cost overruns known from literature review and discussion with consultants. These factors are connected with Owner, Contractor, Consultant, and Management, Material, Equipment, Labor and External. The cost overrun methodology presented in this study gives statistical method which is used in construction sector for computing impact of project cost overruns. The finding of the paper can facilitate the project manager to act on crucial causes and further try to reduce cost overrun of project.

Santosh Kumar prajapati(2016) dig-out information on the factors that cause cost overrun throughout construction and their effects on construction projects in Madhya Pradesh. Questionnaire survey was used to collect data on cost overrun. Twenty seven questionnaires forms from clients, consultants and contractors were collected and a desk study of 34 completed public building construction projects in Madhya Pradesh was investigated and analyzed using descriptive and inferential statistics. From these resultsit had been found that 44 out of fifteen public building construction projects suffered cost overrun. During this analysis, it had been found that with the increase in contract amount the rate of cost overrun decreases. This study is made to find out the causes of cost and schedule overrun in transportation sector in Madhya Pradesh to suggest possible way for reducing such type of overruns. The effects of cost overrun known by this research were delay, and supplementary agreement or adversarial relations among stakeholders, and budget shortfall of project owners. It's thus hoped that these findings will guide to improve the performance of the construction industry in future.

Hiral H. Patel, Chirag J. Shah (DEC 2013) research work has been aimed to look out the causes that are inflicting cost overruns within the construction projects. This research activity was entirely assessed through questionnaire survey. Literatures has been studied for assessment and evaluation of factors that are causing cost overruns in construction industry. The results accomplished from survey disclosed that key causes of delays and cost overruns throughout construction projects are the escalation of the materials prices and discontinuity of funds. The ranking shows that Drawings, Government Policies, Increase in Expenses, Festivals, Investigation or Tests and Specifications are most crucial factors and are responsible for construction cost overruns in South Gujarat (Tapi and Surat District).

\section{FACTORS CAUSING COST OVERRUNS:}

Based on the literature and related work, following are some factors causing cost overruns in construction projects,

\section{Contractor's Site Management Related-}

Contractor's Site management related factors majorly include Rework of bad quality performance. Often it is seen that project participants either the contractor or owner, for their personal benefits compromise with the quality of work. However, in most of the cases such works are to be carried out again as they are not matching the substantial standards. Factors taken under contractor's site management are poor site management and supervision, lack of experience of contractor, mistake during construction, relationship between management and labour, shortage of labour, late delivery of material, shortage of material, problem with sub-contractor, dispute between parties. 


\section{Design Related-}

Design related factors which leads to overruns are critical in construction projects. Often these factors lead to cost increases and affect the project performance. These factors include late in revising and approving of design document by consultant and client, incomplete design, frequent design changes, mistake in design and lack of involvement of contractor during design. Sometimes the time allowed for the preparation of an estimate is less comparing to the size and span of project which often leads to mistake in estimating.

\section{Finance Related -}

Poor Financial condition of owner results in delay of construction project which further increase the cost of construction in favour to complete the project. Improper flow or lack of cash in construction may lead to delayed payments which may force the project participants to withdraw or upheld project leading to overruns. Factors like insufficient fund, delay in progress payment by owner, delay in payment to contractor, change in foreign exchange rate, financial management on site and bankruptcy are some factors that leads to cost overrun if properly not taken into consideration.

\section{Cost Estimating Related-}

During the cost estimation of project if factors like inflation, fluctuation in price of material, transportation cost, high maintenance and cost of machinery, change in material specification, change in orders and poor estimation of original cost occurs then it will directly causes cost overrun.

\section{External Factors-}

Bad weather condition,labour strike,theft on site, unexpected ground condition and act of God are some external factors which may cause delay in completion of work and subsequently lead to cost overruns.

\section{CONCLUSION-}

In this paper, we have studied different literatures related to cost overrun and its causes. We studied various factors which shall be controlled to avoid the effect of cost overrun and minimize the extra cost. Based upon the various literatures reviews various factors causing cost overrun can be identified and with the appropriate method of data analysis. The most significant factors influencing the cost overruns can be analyzed. Based on the reviews it was found that financial condition of owner, cash flow to contractor, drawings, policies, increase in expenses, high transportation cost, change in material specification, material shortage and shortage of labour are some of the factors that yield to cost overrun. Future studies can be done on different types of project like infra structure and different factors should be selected through literature reviews for cost overrun. Thus, it is important to study thesefactors to avoid it for maximum benefits and returns from construction project.

\section{REFERENCES-}

[1] A.M.EL-Kholy"Predicting Cost Overrun in Construction Projects",Civil Engineering Dept., Faculty of Engineering, Beni-Suef University, Beni-Suef, Egypt,International Journal of Construction Engineering and Management 2015, 4(4): 95-105.

[2] Abhimanyu S. Rathi"Study of Factors Influencing Cost Overruns: An Overview", department of Civil Engineering, PRMCEAM, Badnera- Amravati (MS) India,International Journal of Science and Research (IJSR).

[3] Dhanasree S Tejale "Analysis of Construction Project Cost Overrun by Statistical Method", International Journal of Advance Research in Computer Science and Management Studies, Volume 3, Issue 5, May 2015.

[4] Hiral H. Patel, Chirag J. Shah"Priority Indexing of Factors Affecting Cost Overruns using AHP Technique", Civil Engineering Department, S.N.P.I.T \& R.C, Umrakh, Bardoli, Gujarat, India,International Journal of Innovative Research in Science, Engineering and Technology Vol. 2, Issue 12, December 2013.

[5] S.Shanmugapriya, Dr. K. Subramanian"Investigation Of Significant Factors Influencing Time Overruns In Indian Construction PROJECTS" Department of Civil Engineering, Coimbatore Institute of Technology, Coimbatore,International Journal of Emerging Technology and Advanced Engineering, Volume 3, Issue 10, October 2013.

[6] SantoshkumarPrajapati "Causes and Effects of Cost Overrun On Construction Projects in Madhya Pradesh", Civil Engineering Department, ITM University, Gwalior, India, 2016 IJEDR |Volume 4, Issue 2.

International Journal of Engineering Research and Applications (IJERA)is UGC approved Journal with S1. No. 4525, Journal no. 47088.

Shah Mohd Shahbaz. "Study of Factors Causing Cost Overrun in Construction Industry Using AHP Technique: A Review." International Journal of Engineering Research and Applications (IJERA) 7.7 (2017): 86-88. 